\title{
«YOU SUFFER», «НУДОТА» I «РИТМ 0»: ФЕНОМЕНОЛОГІЯ ПАРАМУЗИКИ
}

У статті пропонується новий термін «парамузика» як комунікативні екстремуми музичного. Переживання музичного часу розглядається як сфера напруження між Хроносом та Еоном. Етичні виміри музики пов'язані із подвійною каузальністю подій. Конщепт парамузики вибудувано навколо трьох артефактів: музичної п'єси, фрагмента літературного твору і перформансу.

Ключові слова: парамузика, «Логіка смислу», музичний час, Хронос, Еон, подієвість, комунікативні екстремуми.

В статье предлагается новый термин «парамузыка» как коммуникативные экстремумы музыкального. Переживание музыкального времени рассматривается как сфера напряжение между Хроносом и Эоном. Этические измерения музыки связаны с двойной каузальностью событий. Концепт парамузыки выстроен вокруг трех артефактов: музыкальной пьесы, фрагмента литературного произведения $и$ перформанса.

Ключевые слова: парамузыка, «Логика смысла», музыкальное время, Хронос, Эон, событийность, коммуникативные экстремумы.

The article proposes a new term "paramusic» as communicative extremes of the musical. The experience of musical time is seen as a sphere of tension between Chronos and Aeon. Ethical dimensions of music are associated with the double causality of events. The concept of paramusic is built around three artifacts: a musical piece, a fragment of a literary work and a performance.

Key words: paramusic, "Logic of sense», musical time, Chronos, Aeon, event, communicative extremes.

Я уже не способен припомнить, когда и где произошло событье. То или иное.

Вчера? Несколько дней назад? В воде?

В воздухе? В местном саду? Со мною? Иосиф Бродский

Введення будь-якого нового терміна розмежовує площину невизначеності складкою, не кажучи вже про те, що ускладнює життя теоретику. Якщо ми говоримо про «парамузику», здається, що уся «інша» музика відразу опиняється на протилежному боці. Взагалі, питання демаркації в усі часи було одночасно і болісним, і життедайним для теоретичного музикознавства. Можливо, симптоматичним $є$ той факт, що навіть у Вікіпедії, яка $\epsilon$ надійним показником кодифікації певного дискурсу, окрема стаття присвячена саме визначенню терміна «музика» (Definition of music).

Мартин Гайдегтер, наприклад, не дуже поважав мистецтвознавців, маючи на те свої цілком зрозумілі причини. Певно, прозоро натякаючи, що теоретики мистецтва часто опікуються предметом, не маючи усвідомлення про об'єкт. Справ- ді, універсального і несуперечливого визначення музики не існує і донині. В принципі, це і не дивно, оскільки чим іще бути мистецтву, окрім речі, яка постійно перебуває в стані самозаперечення, ухиляючись від «привласнення» концептом.

Отже парамузика. Дещо парадоксальне твердження, але цілком закономірне, що стане зрозумілим із подальшого тексту: парамузики не існує. Хай там як, але про неї варто говорити. Музикознавці завжди, часом підсвідомо, покладали надії на виявлення певного «концептуального ядра» музики - того, що може постати в результаті послідовної редукції ії «допоміжних засобів». Зрозуміло, що це добре знана модернова центристська модель. Зрозуміло, що тіло музики може бути не лише тілом із ієрархією органів, а й номадичним тілом, як прийнято казати, — «тілом без органів». Втім, часом все ж хочеться собі дозволити «останню утопію», якою наразі виступає парамузика як початок і кінець музики взагалі.

Саме $з$ цих причин парамузика - не «інший» тип музики, не стиль, не жанр, не медіа. Парамузика - спроба дещо змістити фокус у розумінні 
музичного як такого, хоч як би претензійно це звучало. Попередньо скажемо так: парамузика - це смислова межа музики (навіть ліміт у математичному сенсі), горизонт іiї подій. Тому однозначно «викрити» парамузику автоматично означає впевнитись у її відсутності, оскільки цей шлях - шлях Ахілла і черепахи з відомої апорії Зенона. Парамузика - це рух до комунікативних екстремумів музичного, коли саме «людське» перестає схоплюватись, оскільки час врешті-решт долає «інерцію матерії». Ми торуємо шлях від щене-людського до надлюдського. За усієї своєї привабливості, добре відома позиція «усе є музика» (Кейдж, Штокхаузен) навряд чи $є$ продуктивною у сенсі наукової рефлексії. Так само, як і знаменитий тезис про «організований звук» (Варез), який відразу викликає незручні запитання: хто саме цей звук організував і з якою метою. Тому ми все ж припускаємо, що музика існує, отже існують $\mathrm{i}$ певні ліміти їі буття.

Порівняно із такими глобальними проблемами, як окреслення концептуального простору музики «на усі часи», наше завдання видається дещо скромнішим - виявити «регіони складчастості» $\mathrm{i}$ «гравітаційні ефекти» на самій межі «зони смислу» (власне, тієї дифузної зони, що окреслює музичне крізь час). Парамузика - це симптоми початку і завершення музики. 3 огляду на це, зрозуміло, чому парамузики насправді не існує. У цьому контексті немає сенсу говорити про демаркацію - існує лише ефект «згортування», між «ось-ось» і «щойно». Тому «ухопити» парамузику - певно, таке саме складне завдання, як ухопити «момент без товщини» чистого Еону, який заперечує теперішній час і опирається усякій концептуалізації.

Мистецтво відбувається (саме відбувається, a не $\epsilon$ ) на мобільній лінії між валоризованим i профанним (про це свого часу чудово писав Борис Гройс). Ця лінія, власне, розмежовує музичне і екстрамузичне, або, іншими словами, те, що дозволено, i те, що ні. Музика не $\epsilon$ i, в принципі, не може бути «мовою», подібною до вербальної. Однією 3 причин невимовності музики $є$ висока інтенсивність процесів конвергенції і дивергенції комплексу іiі виражальних засобів, який часом (на зламі епох) буквально жадібно всотує в себе чужорідні елементи. Це і не дивно, оскільки музика і не має бути настільки висококонвенціональним утворенням, яким $€$ натуральна мова.

Виживання мови гарантується здебільшого імунними процесами, виживання музики - водночас і імунітетом, і патогенезом. Згодом ДНК вірусних форм, які з часом позбавляються свого вибухового потенціалу, вбудовується у культурне тіло і знаходить своє місце у музеї, стаючи почасти «класикою» (у кращому разі) та набуваючи шансів отримати життя здебільшого у формі ретро-рефлексу (у гіршому разі).

У цьому контексті також можна сказати, що те, що не є музикою, ось-ось нею стане. I навпаки: $з$ часом зона музичного дає свої розколи і прогалини. Але парамузика не є питанням естетики. Швидше це питання логіки самого смислу музичного. Врешті-решт, якщо вухо, згідно з відомим психологічним тезисом, $\epsilon$ аналізатором часу, а музика - способом буття часу, то комунікативні екстремуми (власне, парамузика) - це конфігурації часо-смислу у його граничних випадках.

Очевидно, що таке «відволікання» від естетики, якою традиційно опікуються музикознавці, стало можливим лише сьогодні, коли раптом стало зрозуміло, що все може бути музикою, як, власне, і мистецтвом. У цьому контексті самі естетичні категорії розмиваються, перетворюючись, у кращому разі, на локальні «стильові константи», що є очевидним і невідворотним наслідком краху європоцентризму (як і переосмислення проекту модерну взагалі). Немає сенсу уточнювати, що класична естетика виникла як рефлексія передусім європейських «форм прекрасного».

Можливо, хтось зауважить, що мистецтво завжди опікувалось етичними проблемами. Так, саме «опікувалось», у доволі опосередкованому вигляді, обертаючи те, щуо $\epsilon$, на те, щзо може бути дозволеним, - i навпаки. Але ніколи питання етики не обертались на матеріал для мистецтва, не формували тіло твору (як це можна яскраво простежити, наприклад, на перформансах Марини Абрамович). Принаймні, прикладний сенс цього тезису дає змогу дійти кращого розуміння саме сучасного мистецтва, яке безсоромно здирає власні естетичні покрови, вкриті легким (а почасти і важким) саваном минулих століть. Естетика $\epsilon$ функцією дистанції між реальністю i мистецтвом, з одного боку, захищаючи від занадто сильного проникнення мистецтва у життя, 3 іншого - загострюючи буденне і підсвічуючи його «прекрасним». Так, саме дистанція породжує відоме напруження, оскільки чим іще бути простору порожнечі, як не гравітаційним полем, що виникає внаслідок роз'єднання тіл?

Те, що ми спостерігаємо сьогодні у мистецтві, можна назвати «великим етичним поворотом». Можливо, це остання стадія дивергенції етики і естетики, які у стародавні жорстокі часи були 
синкретично поєднані й узагалі не існували як окремі форми рефлексії. Що сталося, коли раптом все стало естетичним (як писав Жан Бодрійяр, «Трансестетика»)? Кажуть, що мистецтво і життя зблизились, але який характер цього зближення?

Відношення не транзитивне. Менш за все їхнє зближення нагадує дифузію, тобто взаємопроникнення. Коли світ став естетичним, він розчинив у собі мистецтво. Іноді кажуть, що мистецтво дзеркало світу (хоч і доволі криве). Естетика осіла на речах цупкою дзеркальною плівкою, і світ став бачити лише віддзеркалення відображення. Ніхто не може бачити крізь дзеркало, а свого відображення не бачать лише вампіри. Врешті-решт суцільна дзеркальна поверхня - оптична метафора трансестетики. Часом це дзеркало стає чорним, але це не змінює його суті. Гайдеггерівський дазайн (Dasein) набув несправжнього екзистенціалу — як дизайн. У світі дизайну сутність речей прихована.

Краса не врятувала світ, як сподівався класик. Хіба що врятувала від запаморочення власної глибини. А що ж сталось із мистецтвом, яке мало «стати життям»? Воно досі чекає на своїх спустошених дзеркалах повернення того самого «червонуватого рефлексу», що сповіщає про прихід символів крові. Життя поцупило у мистецтва естетику, а мистецтво досі намагається дати симетричну відповідь. Що може бути гідною фігурою у цьому символічному обміні? Тільки те, що $є$ не життям, - те, що може позбавити саме життя його плину.

Завдання-максимум, яке ми ставимо у цій статті (за усієї очевидності принципової невирішуваності даного завдання у заданих обсягах друкованих знаків), - поставити питання не просто про часосмислові конфігурації музики у граничних випадках, а ввести їх до етичних координат наскільки вони торкаються питань свободи, необхідності, долі та страждання. У цьому контексті має сенс навіть такий спрощений тезис: парамузика - подієва етика комунікативних екстремумів. «Викриття» етичного ядра стало можливим лише iз надзвичайним загостренням власне естетичної проблематики музики, яке почалось на зламі епохи модерну, із граничним ущільненням і одночасно розрідженням музичного часу і простору, які неначе вирішили за будь-яку ціну досягти спочатку технічного, а згодом і перцептивного лімітів.

Одна $з$ проблем у обговоренні подібних тем полягає, власне, у самій мові обговорення. Річ не лише у відсутності методології. Зрештою, методологія не гарантує адекватного описання пред- мету. Особливо, якщо пригадати про «три кити» будь-якого аналізу — термінологію, методологію й ідеологію. Якщо прийняти парадигму як систему теорем, то зрозуміло (завдяки Куртові Геделю), що власна аксіоматика залишається «сліпою плямою» аналізу. Аналіз ніколи не встигає за власним предметом, якщо цей предмет - мистецтво. Будьякий чесний аналіз прагне в ідеалі стати метамовою - це справа усього його життя. Метамова на те й «мета-», що трансцендує «першу» мову. Але важко трансцендувати те, що і так $\epsilon$ від природи трансгресивним - як мистецтво. Виходить, що для вирішення свого завдання аналіз мистецтв має бути більшим мистецтвом, ніж саме мистецтво. Так ми наближаємось до простої й очевидної думки: говорити про мистецтво варто мовою самого мистецтва. Якщо не того ж самого виду мистецтва, то принаймні літературно-поетичною мовою. Цим частково і пояснюється дещо вільний стиль цієї статі.

Матеріалом для статті слугують три артефакти, два 3 яких взагалі не є музикою, а третій має сумнівний статус щодо власної музичності. Причому зв'язок між цими трьома скоріше нагадує «квазі-причинну» каузальність, ніж зв'язок здорового глузду. Але, в усякому разі, вони обрані не випадково і мають спільну мету нашого екскурсу - наблизитись до музики у ії граничних проявах. Було б доволі дивним намагатися говорити про парамузику (якої, як було сказано вище, не існує), спираючись на звичний музичний матеріал, у якому, з позиції теоретичного музикознавства, «є, що досліджувати».

Отже самим «музикальним» (і ключовим для цієї статті) із згаданих артефактів $є$ пісня під назвою «You Suffer» («Ти страждаєш») британського колективу Napalm Death. Сьогодні ця пісня, маючи хронометраж усього 1,316 с, вважається, за книгою рекордів Гіннеса, найкоротшою піснею у світі. Вперше пісня 3'явилась у альбомі «Scum» (1987), згодом була випущена у вигляді синглу, який, відповідно, став найкоротшим синглом у світі. Зрозуміло, що з позиції здорового глузду жодними іншими мотивами, окрім гумору, появу цієї пісні пояснити не можна. Але, як це часто буває, концептуальні ідеї просочуються у наш світ непомітно. Текст пісні має одну репліку: You suffer, but why? («Ти страждаєш, але чому?»). Хочеться думати, 3 огляду на подальше викладення матеріалу, що назва пісні - саме цієї пісні! — $€$ не випадковою. Хоча насправді цього ніхто не знає.

Зрозуміло, що у такому граничному випадку, як названа пісня, будь-який теоретичний апарат, 
націлений чи на аналіз гігантських романтичних симфоній Густава Малера, чи на складні серійні опуси П'єра Булеза, відмовляється бути причетним до аналізу, - оскільки аналізувати, власне, немає чого. Пісня є своїм ім'ям, а ім'я є піснею. $€$ певний проміжок часу, явно недостатній для розгортання якихось смислових структур. $€$ певна спектральна щільність - загалом подібна до шуму). Чим є насправді ця пісня? Чому вона має таку назву? Яким чином пов'язана iï назва, ii тривалість і її вибухово-шумовий характер? Ці питання навряд чи колись ставали проблемою для музикознавства - і навряд чи стануть. Навіть «4'33”», за усієї своєї відвертої «немузичності», може надихнути на не один десяток сторінок роздумів про природу музики. Односекундна пісня - у жодному разі.

Яким режимом подієвості характеризується ця пісня? ІІї можна кваліфікувати як «згортання» певної кількості подій до одного (щоправда, дещо «стовщеного») «тепер». Або як одну подію, єдиний звук. Тут можна пригадати відому проблему атомарності музичного часу, як і часу взагалі. Так само, як і проблему смислу і швидкості, що тривожила, часом імпліцитно, і атомістів з їхніми ейдолами, і Маклюєна з Дельозом. Чи взагалі існує «мінімум» смислу? Коли настає межа неосмисленості, на якому часовому інтервалі? Чи може когнітивна психологія і феноменологія сприйняття хоча б частково дати пояснення на цим вічним питанням?

Другий об'єкт - короткий фрагмент роману Жан-Поля Сартра «Нудота». Взагалі, сприйняття часу у романі - тема для окремої рефлексії. Наразі йдеться про специфічне сприйняття саме музики крізь призму екзистенціального світосприйняття Антуана Рокантена, головного героя дійства. За сюжетом, Антуан слухає музику в кафе. Наведемо цитату (переклад Владислава Борсука):

«Ще кілька секунд - i заспіває Негритянка. Потреба в цій музиці просто нездоланна, і ніщо не може урвати ¥ї, ніщо зайшле з цього часу, в якому недбало розвалився світ; музика урветься саме тоді, коли треба. Я люблю цей голос не за його багатство, не за тужливий тембр, а за те, що він подія, яку здалеку підготували стільки нот, які вмерли, аби він жив. I все ж мені бентежно: так мало треба, щоб диск зупинився, - лусне пружина або Адольф щось утне. Яка незбагненна, яка хвильна крихкість цих хвилин. Ніщо не може їх урвати, все здатне їх розбити.

Ось пішов у небуття останній акорд. I далі, за коротку хвилю тиші, я раптом гостро відчув: щзось сталося.
Тиша.

Some of these days

You'll miss me honey!

А сталося те, що Нудота зникла. Тієї миті, як голос співачки забринів на високій ноті, я відчув, що моє тіло напружилось, і Нудота розточилась. Ув одну мить: мені майже боляче почуватись таким твердим, таким осяйним. А музика все ширилась, росла, як смерч. Вона виповнювала залу своєю металевою прозорістю й розчавлювала об стіни наш жалюгідний час» $[4,25]$.

Нарешті, третій артефакт - знаменитий перформанс Марини Абрамович «Ритм 0», вперше явлений публіці у 1974 році. Описувати сам перформанс немає сенсу, та й регламенту, тому лишимо посилання [5]. Зрозуміло, що з усіх трьох об'єктів цей має найменш очевидне відношення до музики. Але, як буде показано нижче, темпоральна етика (або етична темпоральність?) перформансу має безпосереднє відношення до музичних екстремумів, які ми і називаємо парамузикою.

При написанні статті джерелом натхнення і почасти концептуальною основою стала відома книга Жиля Дельоза «Логіка смислу» (1969). Особливо цінною $є$ концепція переживання часу як двох протилежних іпостасей - Хроносу і Еону: тотального «тепер», яке наче «стягує» в себе минуле і майбутнє; і моменту без товщини, який безперервно роз'єднує найдрібніший момент часу на минуле і майбутнє, шо нескінченно віддаляються в обох напрямках.

Аналізуючи «Про сутність істини» Гайдеггеpa, Олександр Койре зауважує, що кінець кінцем мовою справжньої екзистенції $є$ мовчання [2]. Не буде значним перебільшенням сказати, що мовчання $є$ продуктивною межею і музики. Але музика має й інший екстремум. Якщо все ж узяти на віру, що музика $є$ організованим процесом, зрозуміло, що певні події є більш вірогідними, інші менш вірогідними. Чим більше ступенів свободи системи, тим більше музика зміщується до ліміту, коли всі події стають рівновірогідними. Цей ліміт добре відомий, це - білий шум. Можна було б сказати, що це і $\epsilon$ «музика природи», але буття шумить все ж у ритмі $1 / f$ (рожевий шум).

У даному контексті цікаво, що два однакових за довжиною і піковою амплітудою фрагменти білого шуму є за теорією вірогідності максимально несхожими звуками, але разом із тим - максимально схожими за слуховими враженнями. Так ми одночасно досягаємо двох лімітів - подоби і відмінності, що дещо бентежить, але $є$ цілком логічним. Ми звертаємось до банального запитання: 
що робить музику різною і однаковою? Де пролягають кордони розрізнення? Якою є межа подієвості музики? Чи є потенціал смислоутворення нескінченним?

У зв'язку з цим можна як попередню гіпотезу запропонувати три моделі смислової диспозиції. Перша модель має назву ісрархічної. Найвищим досягненням такої форми організації $\epsilon$ «ціле» як системний ефект. (Пригадаймо, що система $\epsilon$ завжди більшим, ніж сума їі складових, — це і має назву «системного ефекту», або емерджентності). При поєднанні у системі ії компоненти також полишають певні якості, які не можуть бути задіяні у системних відношеннях, - це зворотний бік системного ефекту. Тому не буде перебільшенням сказати, що так само, як ціле більше суми складових, так ціле водночас і менше суми складових. Будь-яке відношення взагалі опікується лише обмеженим набором якостей речей, отже - певним чином викривлює реальність. Можна пригадати дотепний приклад з вогнем і бавовною, яким Грем Харман, представник спекулятивного реалізму, чудово ілюструє цей тезис $[6,52]$.

Ієрархічна модель досягає ефекту «цілого» шляхом часткової втрати партикулярного. Причому із рухом до верхніх поверхів ієрархії їхня семантична цінність знижується, отже, варіативність зростає без загрози для ефективної комунікації. Наведемо приклад. Існує, скажімо, 100 різних записів однієї симфонії Бетховена, кожна 3 яких $є$ інтерпретацією оригінального тексту. Але смислове ядро лишається тим самим. Так само можна взяти один із ста записів і відтворити його через 100 різних пристроїв, кожен зі своїм індивідуальним АЧХ і спотвореннями. Але все одно це буде той самий «один із ста» записів, незважаючи на виразні відмінності у звучанні. Ієрархічна модель $\epsilon$ результатом дії одного з основних законів теорії систем - закону ієрархічних компенсацій (закон Сєдова, або Сєдова-Назаретяна). Згідно з цим законом, різноманітність верхніх рівнів системи досягається обмеженням різноманітності нижніх рівнів. I навпаки - розростання нижніх рівнів веде до руйнування різноманітності на верхніх.

Шлях ієрархічної моделі — це фактично шлях європейської музики епохи модерну. Стабілізація нижніх рівнів комплексу виражальних засобів (наприклад, розвиток стандартної нотації, утвердження єдиного строю інструментів, становлення ладотональної системи тощо) спричинила вибуховий зліт різноманітності форм, а стабілізація форм привела до зльоту індивідуальних стилів.
Якщо ієрархію можна прирівняти до дерева, то друга модель - фрактальна - уявляється як, скажімо, дерево без коріння і без завершення, словом, дерево, яке вічно повторює саме себе. Сутність виробництва смислу при такій організації грунтується на нескінченному потенціалі мікроскопічного погляду. Будь-яке наближення викриває у кінці не атомарні структури, а інші структури, що не поступаються складністю попереднім. Не важко здогадатись, що «атомарність» музики, хоча б уявна, значно полегшує ієрархічну організацію, тому музичний звук або тон тривалий час був неприступним муром для музикознавства і своєю стабільністю викликав надію, що система все ж діє.

Коли ієрархія руйнується, кожен іï окремий елемент може стати джерелом нових відкриттів, стратегій, цілих стильових напрямів і композиторських технік. Кожен елемент може бути послідовно «вичерпаний» аж до своїх перцептивних лімітів: наприклад, ритм обертається на мікроритм, що легко досягає межі розбірливості окремих звуків; мікрополіфонія обертається суцільними звуковими плямами. Але, хоч як дивно, ці ліміти не $\epsilon$ остаточними. Справді, перцепція має свої, добре відомі психологам межі, але є один момент, що робить процес звукової мікроскопії концептуально невичерпним.

Фрактальна модель $є$ медіальною. Не лише у тому сенсі, що мікроскопія неможлива без відповідних інструментів, а й у тому, що рефлексія самого інструментарію $€$ потенційно нескінченною. Зазвичай інструменти знаходяться у прозорості власної зручності (як казав Гайдегеер), доки не зламаються. Для виведення інструментів з їхнього потаємного, очевидно, потрібні вже інші інструменти, навіть ті, єдина функція яких полягає у «зламуванні» своїх попередників. Так, скажімо, прозоре віконне скло стає несподівано помітним на якусь мить, коли його розбиває камінь. Уважному слухачеві будь-якої сучасної музики неважко буде помітити, що чимало речей за останні 50 років виникли саме як рефлексія над «зламаними інструментами».

Врешті-решт ми досягаємо третьої моделі. Назвемо її умовно ризоматичною (хоча і не у строго дельозівському розумінні). Ця модель передбачає постійні осциляції між попередніми двома моделями. Відтак тіло музики перебуває у постійній самоорганізації: iї «органи», «центри» і загалом структурні ієрархії постійно виникають i зникають під впливом паразитарного розростання позаструктурних елементів. Зрозуміло, що остан- 
ня модель $є$ найбільш гнучкою, але й найбільш парадоксальною, відтак - складною для «проживання», оскільки смислові координати постійно мігрують.

Можна припустити, що комунікативні екстремуми музики є потенційно більш відкритими саме для фрактальної моделі як такої, що свідомо спрямована на «вичерпування» (принаймні, авторові так здається). Межа складності ієрархічної моделі пролягає у площині пам'яті (оскільки є форма, що потребує розгортання у часі), межа фрактальної моделі зміщується до площини перцепції, що цілком логічно для «мікроскопічної» стратегії смислоутворення. Саме на межі можливостей слуху починаються «зони складчастості». Наприклад, «магія аналогу», «езотеричні девайси», загалом майстеринг як сфера професійної діяльності усе це почасти виходить за межі звичної звукової фізики і торкається архаїчного світу фетишизму i анімізму.

Перформативні мистецтва збурюють простір, завдаючи йому ран. Власне, функція перформативних мистецтв - спричиняти гостре відчуття безтілесного моменту, який або ось-ось настане, або вже щойно настав. Саме тому такі мистецтва особливо старанно уникають сигніфікації і численних, обов'язкових спроб мистецтвознавців нав'язати їм певну «мову». Власне, що таке звук? Звук порушує пружну цілісність простору, спричиняючи поранення. Згодом енергія поглинається всесвітньою ентропією і звуки згасають. Рани простору загоюються у процесі того, як розсіюється тепло. Будь-яка рана незалежно від ії глибини - ефект поверхні, невагома подія чистого Еону, яка сповіщає тілу-простору єдиний атрибут («простий ефект») - бути пораненим. Саме тому у серці музики - невимовний смуток, страждання події, яка приречена на «не-існування», розриваючи кожен найдрібніший момент часу на минуле і майбутнє, що віддаляються від нас нескінченним «лабіринтом прямих ліній». Чому б не піддатись спокусі і хоча б на мить не вважати це головним смислом музики? Є певна гостросюжетність у тому, щоб вивести смисл естетичного дійства за межі естетики, за межі «інтонації», «музичного образу» й інших спорожнілих за століття зловживань слів.

Може виникнути справедливе запитання: чому саме музика викликає такі відчуття? Чи не можна сказати те ж саме щодо будь-якої серії подій? Або взагалі до поодиноких подій? Певною мірою можна, оскільки це $є$ людським переживанням часу, нездоланним ефектом буття-до-смерті.
Але музика є граничним випадком, навіть серед інших перформативних мистецтв, оскільки саме звук $\epsilon$ найбільш часоплинним 3 усіх перцепцій. Подієвість звуку відчувається найбільш витончено і найбільш гостро. Річ у тому, що музика передусім організований процес (принаймні так вважають). Навіть якщо вся «організація» полягає у встановленні лімітів імовірності тих чи інших подій. Врешті-решт, чим є музика, окрім «рихтування» поля імовірності?

Можливо, саме у цьому аспекті потрібно шукати лінію демаркації між музикою і саунд-артом - питання, яке неодмінно тривожитиме навіть найортодоксальніших музикознавців. Можливо, не просто сьогодні (принаймні вітчизняних - точно не сьогодні), але 3 часом - неодмінно. Якщо, звичайно, не вдаватися до спекуляцій про те, що «людина і природа $є$ одним цілим», отже, шурхотіння листя на вітру — така сама музика, як симфонія Бетховена. Тут, звісно, немає місця демаркаціям і усі події мають однакову ціну перед Богом. Але, без жодної неповаги до саунд-арту, навряд чи «4'33"» викликає такі самі гострі відчуття, як симфонія Бетховена. Річ у тому, що часоплинність подій, поєднаних квазіпричинною каузальністю, відчувається набагато гостріше, незважаючи на той факт, що усі події від природи нейтральні, але ми все ж сприймаємо світ як людиномірний, отже не позбавлений причинно-наслідкових зв'язків. Наратив вмирає болісно. Досконалість форми, міцно зв'язаної «солодким очікуванням», має свою пропорційну ціну. Саме про це і йдеться, зрештою, у фрагменті із Сартра.

Певно, зараз не час і не місце дискутувати про сутність музичних подій, оскільки верхня часова межа буде подією всього Еону, а нижня - менша за найдрібніший відрізок часу. Принаймні ми можемо сказати, що $є$ клінамен - найдрібніший синтез, що визначає раптовість подій, передуючи всякому зрушенню [3]. Якщо ми все ж спираємось на людиномірний світ, то межу усякої подієвості можна знайти у перцепції. Так, міждисциплінарна теорія часу Джуліуса Фрейзера починається з відрізка в 1-2 мс як початок усякої подієвості саме у масштабах людського часу.

Згодом настає момент, коли музичний час згортається й індивідуальні події постають у суперпозиції «стовщеного» Tenep, причому товщина цього тепер також має межу у безтілесному моменті Еону. Імплозія часу до єдиного моменту, що розділяє простір «миттєвою раною», момент найвищого страждання, яке випадає на долю музики. «You Suffer» існує у просторі на- 
пруження: між «знаком», як ефектом сповільнення, «осідання» часу (як відомо, знак існує лише між паузами і зупинками), і чистим «дієслівним» становленням. Мандельштам у вірші «Нашедший подкову» писав:

Трижды блажен, кто введет в песнь имя;

Украшенная названием песнь

Дольше живет среди других...

Але що означає — дати ім'я стражданню? Чи не те, що ми прирікаємо страждання на вічне буття - бути вічно повторюваним іменем, оскільки будь-яке ім'я має свою продуктивну межу саме у вічному повторенні (на те воно і ім'я)? Скорботною є праця тих, хто перелічує імена, викликаючи їх до життя, занадто короткого, щоб мати у собі як «жорстокість» архаїчних знаків, так і жорстоку непоступливість твердої матерії.

Що потрібно, аби музика відбулась? 3 одного боку - нічого особливого. 3 іншого - як мінімум, вдалий збіг обставин і цільових причин, що часто буває нелегким завданням - особливо, якщо це музика не усної традиції. Концертна зала, наприклад, є простором ритуалу - усе в ній живе атмосферою цієї невідворотності і передчуттям вечірнього дійства. Те, що має відбутись, - відбудеться попри що. Ритуальні рани простору, що їх завдає звук, - своєрідний обряд ініціації, а налаштування оркестру перед концертом - відтворення першоджерельного хаосу перед актом творення.

У цьому контексті Сартр надзвичайно вдало відзначає крихкість ситуації із медіумом, позбавленим простору ритуального співбуття і водночас наділеним певною невідворотністю циклічного процесу (оскільки завжди можна натиснути на кнопку «Repeat»). У цьому одному фрагменті можна віднайти глибини суперечностей перформативних актів реального часу (live-форми) і тих, що існують за нашим бажанням у записі (хоча наша «свобода волі» у даному контексті також дещо ілюзорна). У наш час, коли сам час, здається, зрікається присягання бути лінійним, ми віддаємо жертву не Хроносу, а жертвуємо ним самим наче «зрізаючи» товщину космічного Tепер, щоб відчути смерть і народження безтілесних Еонів у всій повноті їхніх страждань, переживаючи кожен момент як останній. Але що краще - змушувати страждати себе або прирікати на страждання нескінченного циклічного повторення записане слово, змушуючи його знову і знову вимовляти своє ім'я? Ім'я, одного разу вже примхливо викликане тим, хто добровільно або випадково взяв на себе скорботну місію Автора.
Чому коротка пісня примножує страждання? Власне, не стільки коротка, скільки, у нашому випадку, одномоментна. Ця пісня повністю зливається зі своїм іменем, яке можна повторювати безперервно і вічно, оскільки будь-яке ім'я зазвичай коротше за будь-яку пісню.

Ще один момент, на який слід звернути увагу у Сартра, - це «жертовність» попередніх звуків, котрі віддають життя, підгодовуючи появу того самого Голосу. Власне, у цьому і полягає трагізм форми, яка воліла би бути «кристалом» у одномоментності божественного Хроносу, адже не має іншого виходу, як існувати у темпоральності Еону, спираючись лише на інерцію короткої пам'яті. Врешті-решт форма живе надією пам'яті. 3 часом, у процесі того, як пам'ять із індивідуального тіла переходить до колективного (музеїв, архівів, серверів), іiі м'язи слабшають - це неодмінна ціна за бажання утримати Космос у людському тілі. Відтак втрачає надію і форма - полишаючи неквапне розгортання симфоній на користь шизофонії. Зрештою форма досягає свого перформативного ліміту в одномоментності. Завдати рани, збуривши простір криком, потрібно неодмінно за час, менший від того, який потрібен для втечі від цього крику (оскільки від крику, як правило, хочеться ухилитись).

Форма перестає бути навіть нав'язливою i стає відверто шокуючою. (Під нав'язливістю можна розуміти i екстремум очікуваності того благородного відчуття, яке надавала музика минулих часів.) Тут слід згадати відому когнітивну теорію Девіда Гурона, викладену у кни3i «Sweet Anicipation: Music and the Psychology of Expectation» (2006). Зрозуміло, що у книзі не йдеться ні про естетику, ні, тим більше, про етику. Але сам вислів «sweet anticipation» («солодке очікування») наводить на певні думки щодо мимовільної ностальгії за формою, що утримувала очікування в його ввічливих межах завершених кадансів і коректних модуляцій.

Символи крові, які, здавалося б, надійно витіснені придворним етикетом, сповіщають про своє повернення. Вони часто (можна сказати, в останню половину століття - як правило) починають свою ходу саме $з$ маргінесів культури. Часто непомітно, у ролі жартів, «приколів», медіавірусів - того, що зазвичай вислизає з-під пильного ока дискурсивних практик.

Імплозивні стратегії комунікації обертаються іншою стороною - стороною жорстокості. Згортання часу примножує страждання - лише їхня максимальна концентрація здатна вивести розум 
зі «сну швидкості». Не буде перебільшенням сказати (факт доволі некомфортний для споживача, але вже звичний для мистецтвознавця), що сьогодні, а можливо і давно, мистецтво вже побачило свій екстремум ні в чому іншому, як у тероризмі. Це стає ще більш зрозумілим, якщо пригадати один 3 лейтмотивів пізнього Бодрійяра (хоча 63 «Прозорості Зла»), у чиїй інтерпретації тероризм постає у дещо іншому світлі, ніж про нього зазвичай думають. Абсурдність одномоментної форми, яка цим фактом заперечує саму себе, цілком відповідає просторові культури, який вона пронизує.

Перформанси Марини Абрамович експонують час у його етичних вимірах. Врешті-решт, час ніколи не буває нейтральним. Навіть Хронос, божественне Теnер, пронизаний «стражданням тіл». (Певно, Дельоз не випадково використовує саме це слово.) Якщо Хронос - вимір глибини часу (чому б взагалі у цьому контексті не прийняти «глибину часу» його другим виміром - поряд із власне «часоплинністю»?), то чому б йому не бути «часом страждань»? Хіба він вже не є таким від народження? Перформанси Абрамович фактично наповнюють час болісним очікуванням, тривожними, часом жахливими передчуттями iпевно, найсуттєвіший момент у нашому контексті - ставлять суто етичне питання: які загрози несе у собі бездіяльність? Що відбувається у той час, коли ми просто чекаємо? Здається, сам час при цьому набуває щільності твердого тіла - настільки він матеріальний і тілесно-відчутний.

Здавалося б, яке у контексті цієї статті «Ритм 0» має відношення до музики, окрім назви? Але що $є$ назва? Хіба «You Suffer» — це взагалі музика? Музика, від якої залишилась сама назва. Ритм, виходячи за його суто музичне, вузьке розуміння, $\epsilon$ навіть не формою переживання часу, а площиною зіткнення Еону і Хроносу, відтак маючи свої ліміти у безкінечній розрідженості, коли весь час Космосу розпадається на величезне «ось-ось» і гігантське «щойно», які обрамляють єдиний удар цього ритму, і нескінченній щільності — коли усі можливі події застигають у одномоментності.

Ритм відміряє і життя, і страждання. У цьому сенсі назва «Ритм 0 », певно, найбільш органічною для цього перформансу. Ритм організований предметно - його формують безтілесні події, що виникають у точці зіткнення двох тіл. Власне сам перформанс і $є$ цей ритм. 73 тіла (художниця і 72 предмети) у замкненому просторі сповіщають одне одному прості атрибути - «бути пораненим» або «мати здатність бути тим, що завдає рани». «Абсолютна лотерея», про яку пи- сав Борхес, є чужою глибинному вимірові часу. У Еоні немає місця стражданням. Клінамен не знає жалю. Те, що відбувається під час перформансу, - спроба переміщення фокуса погляду на процес самоорганізації як на етичний феномен. $\mathrm{Te}$, що вважалось випадковим, перетворюється на невідворотне. Ритм подій здобуває причинність.

У даному контексті художника можна прирівняти до стоїка-мудреця, який ототожнюється 3 квазіпричиною. Він знаходить себе на прямій лінії, що пробігає поверхнею. Якщо бути більш точним, він - випадкова точка, що блукає цією лінією. Тут мудрець очікує подію, розуміючи іiі у істинній суті, незалежною від часопросторового буття - як те, що має ось-ось відбутись або щойно відбулось на лінії Еону $[1,192]$. Але у той же час мудрець бажає втілення цієї безтілесної події у положенні речей і у власному тілі. Ототожнюючи себе з квазіпричиною, мудрець прагне «дати тіло» безтілесному ефекту, оскільки ефект має мати причину. Мудрець наче намагається «заглибити» Еон у Хронос, надати подіям ваги і значення, дещо «сповільнити» безумне становлення. Як писав Жо Боске, «моя рана існувала до мене, я народжений ії втілити» $[1,195]$.

Що означає цифра «0» у назві перформансу? 3 одного боку - фактор випадковості, як кінець будь-якого ритму. Ритм самого перформансу може урватись у будь-який момент. Пригадаємо знову Сартра: хвилювання героя 3 приводу крихкості ситуації, що може припинитися через будь-яку дрібницю. У «Ритмі 0» випадкова зупинка досягає статусу невідворотності. Якщо у концертному залі гостро відчувається невідворотність початку, то із перформансом ситуація дещо інша - інтригою лишається саме фінал. Це не той фінал, яким завершується симфонія, хоча б тому, що фінал симфонії відомий і настає у лише один передбачуваний спосіб. «Ритм 0 » - симфонія невизначеної довжини із вкрай відкритим фіналом. I це жахає.

Розуміння парамузики, як комунікативних екстремумів, неможливе без усвідомлення природи часу у сукупності його двох режимів (Хроносу i Еону). Власне, напруження, яке створює музика (те, що робить музику відмінною від, скажімо, саунд-арту) своєю течією - це не що інше, як екзистенціальна тривога, пов'язана із подвійним переживанням часу. Музика балансує на межі абсолютної нейтральності подій-ефектів і їхньої квазіпричинності, коли ефекти $є$ не результатом суміші та страждання тіл, а причиною одне одного. Музична форма, як така — пряма лінія, що збирає на поверхні лабіринт подій у їхній квазі- 
причинності, оскільки реальних причин у цих звуків немає - принаймні у тій послідовності, у якій вибудовується наратив.

Музика $є$ наочним прикладом того, як безтілесні ефекти справді намагаються полишити фізичну причину свого виникнення, оскільки причина загрожує їхньому існуванню - таким $є$ парадокс «подвійної каузальності». Можливо, тому у Сартра фігурує абстрактна Негритянка. Зрештою, як писав Беккет, «яка різниця, хто говорить». Згідно з цією реверсивною логікою, сама форма «живого» концерту — не більш, ніж нагадування, що все ж каузальність $є$ подвійною, і в усякого звуку $є$ своя фізична причина, яку іноді корисно бачити на власні очі.

Переживання музичного часу має свої «крайні точки» - туди і спрямований наш погляд у намаганнях вхопити парамузику. А як щодо простору? Якщо взагалі припустити, що простір, яким ми його знаємо, є не лише результатом сповільнення, «осідання» енергетичних потоків - відтак все одно $\epsilon$ ефектом часу. Екстремуми музичного простору - це занурення у час Хроносу, коли з темних глибин раптом постає запитання: «А що, як усе насправді пов'язане?» Дискусійним залишається питання, чи справді «форма-кристал» існує, хоча б у свідомості музикознавців, чи не $\epsilon$ вона результатом миттєвого синтезу - згортання подієвого часу до одномоментності? Чи взагалі не $\epsilon$ просторові уявлення результатом ущільнення i розрідження музичного часу? Оскільки чистий Хронос $є$ лише божественним промислом. Або поглядом того, хто може дивитись на наш чотиривимірний світ із п'ятого виміру.

Що ми знайшли в результаті нашого короткого екскурсу? «You Suffer» - приклад не стільки гумору і абсурду, скільки неочікуваний бік імплозивних стратегій комунікації, загострення ситуації напруження між «живим» і «записаним». Що $є$ «записане» — вічне життя або вічно повторюване вмирання? Саме це питання ставить ця начебто курйозна історія. Колапс музичної форми до одномоментності обертає звичний світ каузальності раною простору, миттєвим вибухом дієсмислу, що передує усякому значенню.

Сартр ставить питання про етичні виміри подієвості, висвітлюючи квазіпричинність у сенсі необхідності, вивільняючи через свого героя най- очевидніші, але й часом найбільш таємні у своїй прозорості, екзистенціали музики: бути не тільки і не стільки бажаною, себто хвилюючою слух своїми формами і наративами, скільки болісно-екстатично очікуваною - що, на мій погляд, дещо виводить нас із сфери естетики.

Перформанс Абрамович, окрім очевидного смислу, який елементарно ідентифікується уважним глядачем, запрошує нас у світ «абсолютної гри» та ii етичних вимірів, коли художник ототожнює себе 3 мудрецем-стоїком. Події раптом спиняють своє ковзання по поверхні й болісно западають у тіло, і сам безтілесний Еон, здається, відступає у запаморочливі глибини.

\section{Джерела та література}

1. Делёз Ж. Логика смысла / Ж. Делёз ; пер. с фр. Я. И. Свирского. - М. : Академический Проект, 2011. - 472 с.

2. Койре А. Философская эволюция Мартина Хайдеггера / А. Койре [Электронный ресурс]. - Режим доступа : http://www.ruthenia.ru/logos/number/1999_10/06.htm

3. Розов А. Клинамен Лукреция - физика и свобода воли / А. Розов [Электронный ресурс]. - Режим доступа : http:// rumagic.com/ru_zar/sci_philosophy/rozov/0/j5.html

4. Сартр Ж.-П. Нудота. Мур. Слова / Ж.-П. Сартр ; перекл. 3 фр. В. Борсука та О. Жупанського ; післямова Н. Білоцерківець. - К. : Основи, 1993. - 464 с.

5. Станіславська К. І. Сучасні перформативні практики: образотворчість чи театралізація? (На прикладі творчості Марини Абрамович) / Катерина Станіславська // Науковий вісник КНУТКіТ імені І.К. Карпенка-Карого : зб. наук. праць. - К. : КНУТКіТ, 2015. - Вип. 16. - С. 154-160.

6. Харман Г. Четвероякий объект: Метафизика вещей после Хайдеггера / пер. с англ. А. Морозов и О. Мышкин. Пермь : Гиле Пресс, 2015. - 152 с.

\section{References}

1. Delyoz, Zh. Logika smyisla / Zh. Delyoz ; per. s fr. Ya. I. Svirskogo. - M. : Akademicheskiy Proekt, 2011. — $472 \mathrm{~s}$.

2. Koyre, A. Filosofskaya evolyutsiya Martina Haydeggera / A. Koyr. - Retrieved from: http://www.ruthenia.ru/logos/ number/1999 10/06.htm

3. Rozov, A.Klinamen Lukretsiya - fizika i svoboda voli / A. Rozov. - Retrieved from: http://rumagic.com/ru_zar/ sci_philosophy/rozov/0/j5.html

4. Sartr, Zh.-P. Nudota. Mur. Slova / Zh.-P. Sartr ; perekl. $\mathrm{Z}$ fr. V. Borsuka ta O.Zhupanskoho ; pisliamova N. Bilotserkivets. - K. : Osnovy, 1993. - $464 \mathrm{~s}$.

5. Stanislavska, K. I. Suchasni performatyvni praktyky: obrazotvorchist chy teatralizatsiia? (Na prykladi tvorchosti Maryny Abramovych) / Kateryna Stanislavska // Naukovyi visnyk KNUTKiT imeni I. K. Karpenka-Karoho : zb. nauk. prats. - K. : KNUTKiT, 2015. - Vyp. 16. - S. 154-160.

6. Harman, G. Chetveroyakiy ob'ekt: Metafizika veschey posle Haydeggera / per. s angl. A. Morozov i O. Myishkin. Perm : Gile Press, 2015. — $152 \mathrm{~s}$ 